\title{
Pseudocercospora macadamiae sp. nov., the cause of husk spot of macadamia
}

\author{
Vyrna Beilharz $^{\mathrm{A}, \mathrm{C}}$, P. E. Mayers ${ }^{\mathrm{B}}$ and I. G. Pascoe P $^{\mathrm{A}}$ \\ ${ }^{A}$ Institute for Horticultural Development, Department of Primary Industries, \\ Private Bag 15, Ferntree Gully Delivery Centre, Vic. 3156, Australia. \\ ${ }^{\mathrm{B}}$ Department of Primary Industries, Queensland Horticulture Institute, Maroochy Research Station, \\ Nambour, Qld 4560, Australia; present address: PO Box 207, Woombye, Qld 4559, Australia. \\ ${ }^{\mathrm{C}}$ Corresponding author; email: vyrna.beilharz@nre.vic.gov.au
}

\begin{abstract}
Pseudocercospora macadamiae sp. nov. is described from diseased husks of plantation-grown
\end{abstract} Macadamia integrifolia in Queensland and northern New South Wales, Australia.

\section{Introduction}

During a continuing taxonomic study by the first author of cercosporoid pathogens of Australian native plants, symptoms have usually been observed on vegetative parts (leaves, phyllodes or occasionally petioles) of affected plants from a wide range of genera. A striking exception to this generalisation is the damaging and economically important husk-spotting disease of Macadamia integrifolia, its cultivars and its hybrids with $M$. tetraphylla (Proteaceae). In nature, the disease is restricted to the husk (pericarp) of the fruit. Foliar, petiole or twig symptoms have not been observed under Australian conditions despite epidemics developing annually in mature orchards. Husk spot has been reported only from Australia, more specifically from Queensland and New South Wales.

In 1951, B.L. Oxenham deposited the first known Australian herbarium specimen of husk spot (as Cercospora sp.), from Nambour, Qld (BRIP 4604). J.H. Simmonds collected the second specimen, also identified as Cercospora sp., in 1971 from Maleny, Qld (BRIP 6137). With the exception of one specimen collected by R.D Fitzell at Whian Whian, NSW, in 1992 (DAR 68433), all specimens of macadamia husk spot deposited in eastern Australian plant pathology herbaria between 1981 and 2001 were provided by the second author who studied the disease during those years and who identified the causal pathogen as a species of Cercoseptoria, a genus into which similar cercosporoid taxa had been placed by Deighton (1976). Following Deighton's (1987) recombination of a number of species of Cercoseptoria, including the type species $(C$. chamaescyses (Stev. \& Dalbey) Petrak), into Pseudocercospora, the macadamia fungus is best treated as a Pseudocercospora and is described in this paper as a new species.

Macadamia is the only plant indigenous to Australia that has been developed into an edible food crop industry. The current value of the macadamia nut crop is $\mathrm{A} \$ 100 \mathrm{~m}$ at the farm gate, the nuts being exported to the USA, Europe and parts of Asia, including Japan.

Macadamia nuts are enclosed in a leathery (fleshy) green fibrous husk which is commonly $3 \mathrm{~mm}$ thick and which, when stripped from the fruit ('de-husking'), exposes a conical to spherical or slightly flattened hard brown shell (testa) $17-35 \mathrm{~mm}$ in diameter. At opposite poles of the nut the smooth to slightly rough shell surface bears a broad hilum scar and a white circular to elliptical micropyle pore that is usually $1 \mathrm{~mm}$ wide but can be up to $3 \mathrm{~mm}$ wide. Enclosed is the creamy white kernel consisting of an embryo and the two edible cotyledons.

Depending on cultivar and region, the macadamia crop is usually mechanically harvested on two or more occasions throughout the progressive nut-fall period (February to October), as hand picking is too expensive and impractical on a large scale. Most growers harvest only from the ground, the harvesting machine at the same time de-husking those fruits which are freshly fallen and from which the husk has not already dehisced. Cultivars tolerant of the disease have been identified as those that sustain only cosmetic damage to the husk and which hold their crop until full maturity (which may be as late as September), whereas intolerant cultivars drop their infected crop prematurely or early. In the latter case, commercial crop yield is reduced by up to $40 \%$ because of the need to discard the first pre-harvest cleanup of 
immature diseased nuts. In fact, healthy and diseased nuts of some cultivars fall simultaneously and continuously for 6-8 months of the year, and consequently are harvested as mixed populations of healthy and diseased nuts which cannot be distinguished after they are dehusked. Quality parameters, including nut roasting and shelf life, kernel discoloration and pinching, are adversely affected by the disease-induced drop of immature nuts being admixed with subsequent harvests. Higher sugar levels are present in immature kernels because the sugars have not been fully converted into oils.

In contrast to unselected trees in their natural habitat, which may flower throughout the year, commercial cultivars of $M$. integrifolia (and its hybrids with $M$. tetraphylla) flower mainly in September and October. Disease expression is first seen in December and January, and marked disease symptoms are evident on 4- to 5-month-old nuts. Field inoculation experiments have shown the optimum nut size for infection to be $12-14 \mathrm{~mm}$ in diameter. Early symptoms of the disease are pale chlorotic spots with diffuse margins, $2-10 \mathrm{~mm}$ in diameter, on the developing husks. As the disease progresses, the lesions may coalesce into irregular blotches, or become circular, zonate 'cat's eyes' which are orange, tan or brown and which develop necrotic centres. The developed lesions are often covered with a thin to felty, pale-brown mass of external hyphae. No fully resistant cultivars of $M$. integrifolia have been found, but breeding for tolerance, combined with cultural and fungicidal control measures, is proving effective in limiting the impact of the disease.

\section{Taxonomy}

Pseudocercospora macadamiae Beilharz, Mayers \& Pascoe, sp.nov. (Fig. 1)

Etym: from Macadamia, the host genus.

Mycelium immersum intercellulare, pallide brunneum, ex hyphis septatis ramosis anastomosantibus $1.75-4 \mu \mathrm{m}$ latis compositum. Mycelium superficiale ex stromata substomatis vel stromata erumpentia ad basim formatum, ex hyphis pallide olivaceo-brunneis laevibus ramosis septatis anastomosantibus $\quad 1.5-3.5 \mu \mathrm{m}$ latis compositum; conidiophora terminalia vel lateralia ex mycelio vegetativo formata, 1-3 septata, 20-59 $\mu \mathrm{m}$ longa $\times$ c. $3 \mu \mathrm{m}$ lata. Stromata subepidermalia vel substomatalia, pallide- vel medio-brunnea, compacta, ex textura angularis composita; stromata subepidermalia erumpentia, c. 34-90 $\mu \mathrm{m}$ diam. $\times$ 20-64 $\mu \mathrm{m}$ profunda; stromata substomatalia non alta, cum massa parva cellularum tumidarum supra stoma demum evoluta. Conidiophora pallide olivaceo-brunnea cylindracea curvata vel sinuata saepe 1-3 ramosa, laevia vel verruculosa, anastomosantia, usque 10-septata, 20-95 $\mu \mathrm{m}$ longa $\times$ (2-)2.5-3.5 $\mu \mathrm{m}$ lata. Loci conidiogeni 1-3, non-incrassati, non-fuscati, plerumque $2.5 \mu \mathrm{m}$ diam. Conidia solitaria, pallide olivaceo-brunnea filiformia curvata sinuata vel recta, apicem obtusum versus leniter deminuta, basim versus interdum leniter diminuta, (0-)5-9 septata, (17-)45-69 $\mu \mathrm{m}$ longa $\times 2-2.5 \mu \mathrm{m}$ lata. Hila leniter convexa, non-incrassata, non-fuscata.

Lesions on the husk epicarp (outer surface) are circular or irregular and initially chlorotic, later necrotic in the centre with an orange, tan or brown margin. The central necrotic zone shows pale-brown, felty fungal colonies which sporulate profusely. The fungus extends through the mesocarp, which becomes tan or light-brown and fibrous due to the development of sclerified tissue, and into the endocarp. The inner surface of the husk can appear water-soaked and later pale-brown, in correspondence with the external lesions. On mature husks of most cultivars, the endocarp is brown to dark brown, largely obscuring the lesion. Immersed mycelium intercellular, light brown, septate, branching, anastomosing, 1.75-4 $\mu \mathrm{m}$ wide, the broader hyphae often being constricted at the septa. Superficial mycelium profuse on some lesions, emerging mainly from the stomata but also developing from the bases of erumpent stromata, pale olivaceous brown, smooth, branching, septate, anastomosing, 1.5-3.5 $\mu \mathrm{m}$ wide, bearing lateral and terminal conidiophores or conidiogenous cells which are delimited by a basal septum, have $0-2$ additional septa, and are 20-59 $\mu \mathrm{m}$ long $\times$ c. $3 \mu \mathrm{m}$ wide. Stromata subepidermal or substomatal, light to medium brown, irregular, compact, composed of textura angularis; subepidermal stromata become protuberant following rupture of the epidermis and cuticle, 34-90 $\mu \mathrm{m}$ wide $\times$ 20-64 $\mu \mathrm{m}$ deep; substomatal stromata shallow, giving rise to a few hyphae which pass through the stoma and proliferate to form a small external knot of swollen cells on which numerous caespitose conidiophores are borne. Conidiophores light olivaceous brown, cylindrical, curved or sinuate, often 1-3 branched or bifurcating, smooth or verruculose, having a slight swelling below some septa, anastomosing, up to at least 10-septate, 20-95 $\mu \mathrm{m}$ long $\times$ (2-)2.5-3.5 $\mu \mathrm{m}$ wide. Conidiogenous loci not darkened, unthickened, non-refractive, left on sloping shoulders following 1-3 sympodial proliferations of the conidiogenous cell, mostly $2.5 \mu \mathrm{m}$ diam. Conidia formed singly, pale olivaceous brown, filiform, curved, sinuate or straight, usually tapering slightly to an obtuse apex and narrowing slightly if at all towards a flared, slightly convex base, (0-)5-9 septate, $(17-) 45-69 \mu \mathrm{m}$ long $\times 2-2.5 \mu \mathrm{m}$ wide. Hila not darkened, unthickened, non-refractive, $2-2.5 \mu \mathrm{m}$ diam. Spermogonia forming within conidiomatal stromata or de novo, uniloculate and lenticular or 2-3 loculate, with pale olivaceous walls 3-5 cells thick and opening by a split; some lesions in VPRI 22745 showed a broad band of spermogonia, some of which were oozing yellowish-green cirrhi, surrounding a central field of conidiomata. Spermatiophores lining the spermogonial cavities are pale, subulate, straight to curved, 0-3 septate, often with 1-2 branches inserted below septa, mostly $25-40 \mu \mathrm{m}$ long $\times 1.5-2 \mu \mathrm{m}$ wide. 


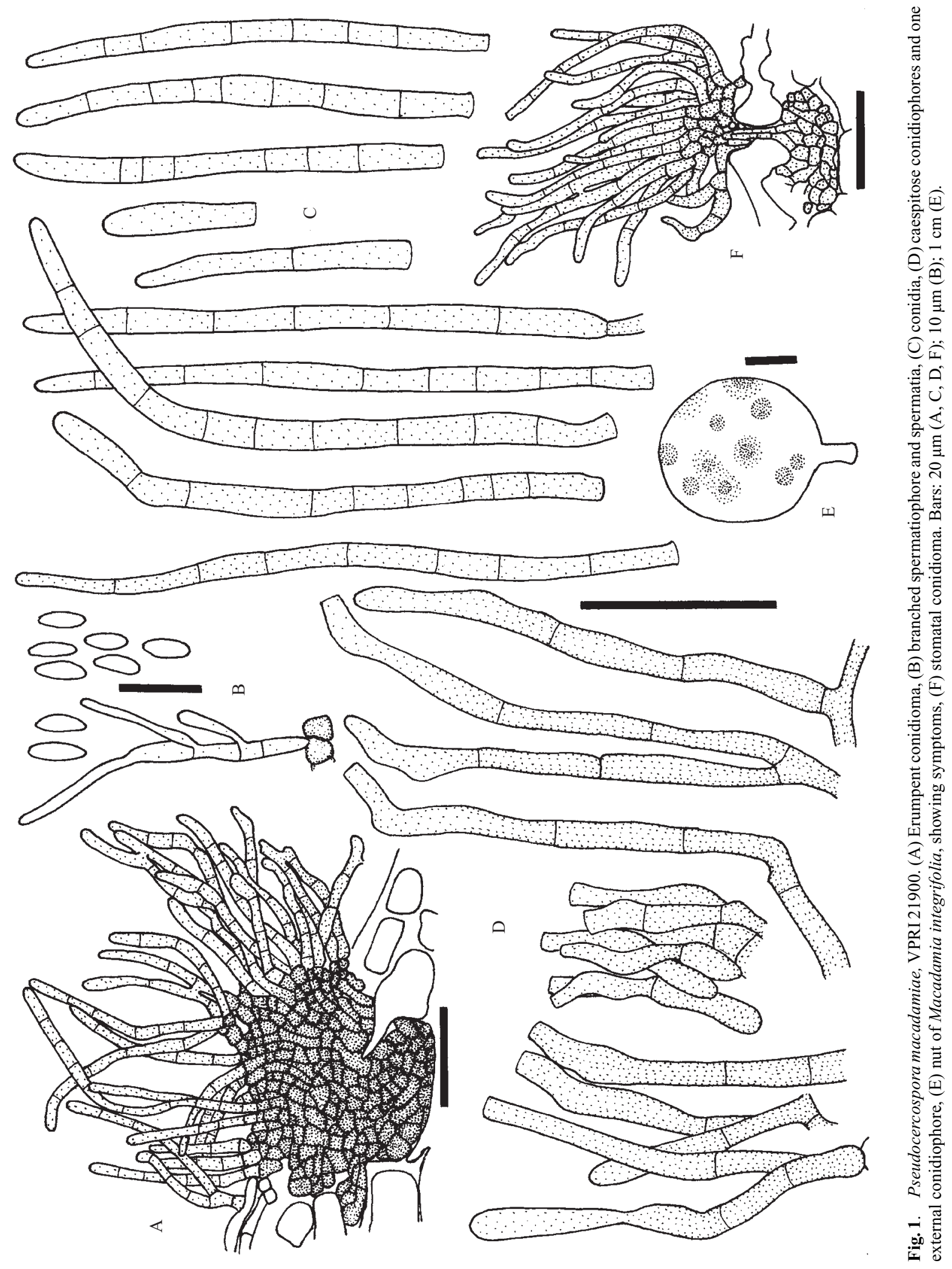


Spermatia hyaline, fusiform, with a minute flattened basal scar, 6-7 $\mu \mathrm{m}$ long $\times 2-2.5 \mu \mathrm{m}$ wide.

Holotype: Australia, Qld, on living husks of Macadamia integrifolia Maiden \& E.Betche cv. H2 (Proteaceae), Sahara Farms, Sahara Rd, Glasshouse Mountains, 5 Feb. 1999, P. Mayers, VPRI 21900.

Additional specimens examined: Qld: on M. integrifolia (as M. ternifolia F. Muell.), Nambour, B.L. Oxenham, 6 Apr 1951, BRIP 4604; on M. integrifolia, ibid, Maleny, J.H. Simmonds, 6 May 1971, BRIP 6137; on M. integrifolia. cv. Hinde, ibid, 17 Feb 1981, P.E. Mayers, BRIP 13798; on M. integrifolia cv. Own Choice, Didillibah, 20 Aug 1985, P.E. Mayers, BRIP 14869; on M. sp., ibid, 12 Aug 1985, P.E. Mayers, BRIP 15051; on M. sp., Maleny, 1985, P.E. Mayers, BRIP 15059; on M. integrifolia cv. 508, Peachester, 10 May 1991, P.E. Mayers, BRIP 18131; on M. integrifolia, Maleny, 19 Aug. 1991, P.E. Mayers, BRIP 19467. N.S.W.: on M. integrifolia cv. Hinde (H2), Clunes, 16 Mar 2001, P.E. Mayers, VPRI 22745; on M. integrifolia cv. Own Venture, ibid, 16 Mar 2001, P.E. Mayers VPRI 22746; on M. integrifolia cv. HAES 344, ibid, P.E. Mayers, VPRI 22747; on M. integrifolia cv. NG 18, ibid, P.E. Mayers, VPRI 22748; on M. integrifolia cv HAES 781, ibid, P.E. Mayers, VPRI 22749.

P. macadamiae is one of a number of Pseudocercospora species which fit the description of the former genus Cercoseptoria Deighton (Deighton 1976) which Deighton himself subsumed into Pseudocercospora in 1987. Cercoseptoria was typified in part by its pale-brown, narrow, acicular, multiseptate conidia which are not obclavate, but rather taper gradually from close to the base towards the apex. Whereas Cercoseptoria was specifically described as sporulating from substomatal stromata, the macadamia fungus sporulates also from large sub-epidermal stromata and from external hyphae.

These variations in mode of egress and sporulation are not considered taxonomically significant in the cercosporoid fungi, and the relative presence or absence of stromata is now regarded as being not a useful distinguishing characteristic at the generic level in Mycosphaerella anamorphs (Crous et al. 2001). Stomata are relatively sparse on the epidermis of the macadamia husk, and sporulation from substomatal stromata probably contributes much less to propagule dissemination than does the sporulation from the larger and more numerous erumpent stromata. Vertical sections through several erumpent stromata have shown conidiophores emerging through a rupture in the epidermis very close to a stoma, even though stomatal egress would appear to be a more energy-efficient mode of egress. Beilharz (1994) has observed this behaviour in several other species of Pseudocercospora including P. correae B. Sutton \& Pascoe (in Sutton et al. 1987) and a photograph published by Evans (1984, Fig. 113) shows a similar occurrence in Pseudocercospora pinidensiflorae (Hori \& Nambu) Deighton on pine needles.

Two other species of Pseudocercospora are known on hosts in the Proteaceae. P. protearum (Cooke) U. Braun \& Crous (in Braun and Hill 2002) and P. stromatosa J.E. Taylor $\&$ Crous (Taylor and Crous 2000) both differ from P. macadamiae in the characteristics and dimensions of their conidiophores and conidia.

\section{Acknowledgements}

The authors express their thanks to J. Alcorn (BRIP) for the loan of herbarium specimens, to J. Walker for correcting the Latin diagnosis, and to N. Leist, J. Cunnington and $\mathrm{S}$. Ford for critically reading the manuscript.

\section{References}

Beilharz VC (1994) Cercosporoid fungi on Australian native plants. $\mathrm{PhD}$ Thesis, University of Melbourne.

Braun U, Hill CF (2002) Some new micromycetes from New Zealand. Mycological Progress 1, 19-30.

Crous P, Kang J-C, Braun U (2001) A phylogenetic redefinition of anamorph genera in Mycosphaerella based on ITS rDNA sequence and morphology. Mycologia 93, 1081-1101.

Deighton FC (1976) Studies on Cercospora and allied genera. VI. Pseudocercospora Speg., Pantospora Cif. and Cercoseptoria Petr. Mycological Papers (CMI) 140, 1-168.

Deighton FC (1987) New species of Pseudocercospora and Mycovellosiella and new combinations into Pseudocercospora and Phaeoramularia. Transactions of the British Mycological Society 88, 365-391.

Evans HC (1984) The genus Mycosphaerella and its anamorphs Cercoseptoria, Dothistroma and Lecanosticta on Pines. Mycological Papers (CMI) 153, 1-82.

Hill CF, Braun U (2002) Some new micromycetes from New Zealand. Mycological Progress 1, 19-30.

Sutton BC, Pascoe IG, Sharma IK (1987). Pseudocercospora correae sp. nov., a leaf pathogen of Correa species from Australia. Australian Journal of Botany 35, 227-234.

Taylor JE, Crous, PW (2000) Fungi occurring on Proteaceae: new anamorphs for Teratosphaeria, Mycosphaerella and Lembosia, and other fungi associated with leaf spots and cankers of proteaceous hosts. Mycological Research 104, 618-636.

Received 24 October 2002, accepted 19 February 2003 